\title{
On the valuation of ecosystem services in Muránska Planina National Park (Slovakia)
}

\author{
Radoslav Považan, Michael Getzner \& Juraj Švajda
}

Keywords: Muránska Planina, valuation, ecosystem services, use values, non-use values

\section{Abstract}

The quantification and economic valuation of ecosystem services is vital to ascertain the social and economic benefits of establishing and managing protected areas. In Central Europe a wide range of studies has emphasized the significant contribution of protected areas to the conservation of biodiversity. This paper provides further evidence on the significance of (non-market) ecosystem services in Muránska Planina National Park (NP), Slovakia, which can be valued at about EUR 10 million per year. However, the ecosystem services of the park provided in terms of forestry, agriculture and tourism are smaller than in other Slovak NPs. In particular, recreation benefits are smaller because of a lower number of tourists (30000 per year) and a lower average length of stay (2.29 days). The study nevertheless underlines the important ecosystem services that Muránska Planina NP provides for the regional and national economy, and how it contributes significantly to human well-being.
Profile

Protected area

Muránska Planina

National Park

Mountain range

Carpathians

Country

Slovakia

\section{Introduction}

From an ecological point of view, the conservation of biodiversity - i.e. the diversity of genes, species, ecosystems and landscapes - provides the foundation for many ecosystem services paramount to human well-being and regional development, and decreases, for instance, the risk of unfavourable ecosystem changes and of the spread of alien species and pathogens. These ecosystem services are vital for humans (Sabo et al. 2011). The outstanding importance of biodiversity is also reflected in the great variety of scientific and political initiatives in this context. The Economics of Ecosystems and Biodiversity (TEEB 2010) programme has put the cost of decreased terrestrial ecosystem services (worldwide) at EUR 50 billion per year. The benefits offered by biodiversity conservation are often not considered adequately. The concept of ecosystem services was developed about 20 years ago (Ehrlich \& Ehrlich 1992; Constanza et al. 1997) and mainly involves benefits to people from ecosystems through the processes that take place in the ecosystem or at a lower ecological system level (Reid et al. 2005).

Ecosystem functions provide ecosystem goods and services, for example, firewood, food, clean air, drinking water or soil fertility (Stohlgren et al. 1999) and thus benefit human health or economic well-being (Lyons et al. 2005). The best known and most used classification of ecosystem products and services is described in the Millennium Ecosystem Assessment (Reid et al. 2005). This document shows the mutual dependencies between ecosystem products and services, biological diversity and human well-being. Constanza et al. (1997) assessed 17 global ecosystem services for 13 terrestrial and 3 sea ecosystems, and calculated their

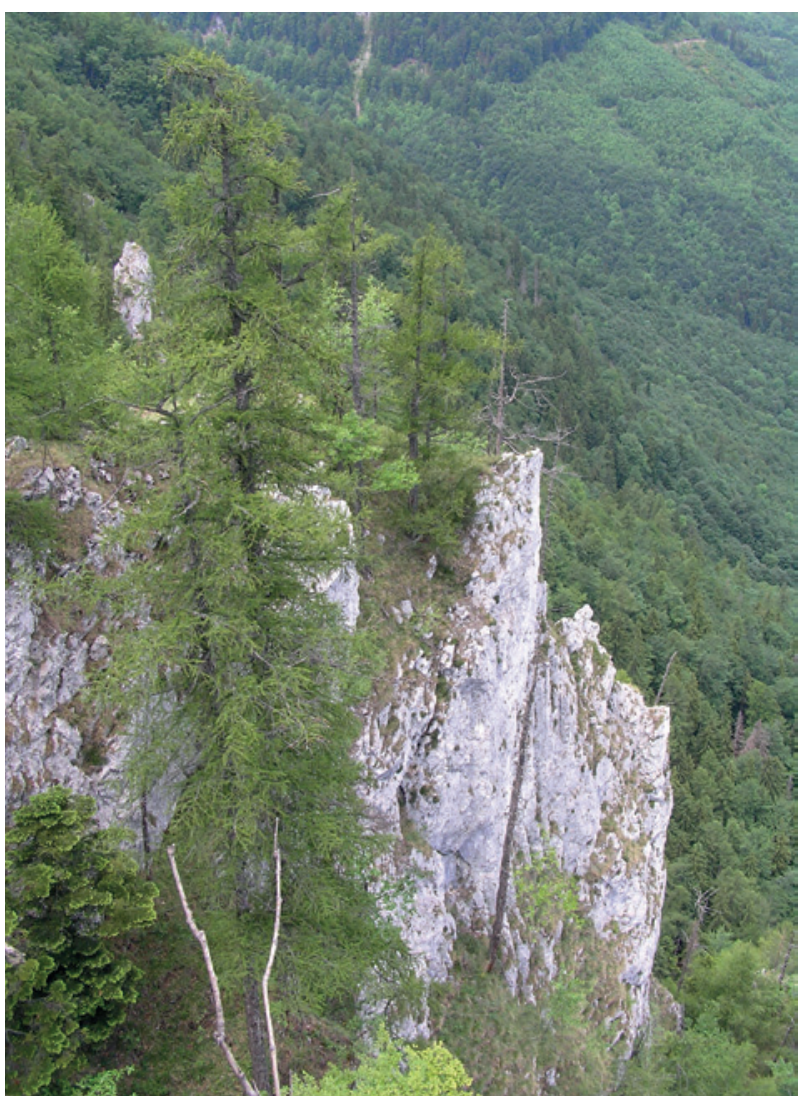

Figure 1 - An impression on Muránska Planina NP. (C) R. Povazan

total value as USD 33 trillion per year. Several types of ecosystem benefits can be distinguished (Pearce \& Moran 1994), which may be aggregated to the Total Economic Value (TEV) of biodiversity, consisting of Use Values (direct, indirect and option) and Non-Use Values (bequest, existence, intrinsic). 
Table 1 - Valuation of ecosystem services provided by Muránska Planina NP.

\begin{tabular}{|l|l|r|}
\hline & Ecosystem services & Value (EUR/year) \\
\hline 1 & Forest products & 3549308.65 \\
\hline 1.1 & Timber & $740.00+49150.00$ \\
\hline 1.2 & Other forest products (seeds, honey) & 975975.00 \\
\hline 1.3 & (Drinking) water supply, water sources & 728377.92 \\
\hline 1.4 & Water retention, flood protection & 56343.36 \\
\hline 1.5 & Carbon sequestration & See 1.4 \\
\hline 1.6 & Erosion control & n. a. \\
\hline 1.7 & Medicinal sources & n.a. \\
\hline 2 & Agriculture & n.a. \\
\hline 2.1 & Grazing, livestock & n. \\
\hline 2.2 & Food production & 53525.00 \\
\hline 3 & Fishing & 4490232.00 \\
\hline 4 & Hunting & $\mathbf{1 0 1 0 6 4 9 9 . 4 3}$ \\
\hline 5 & Recreation & n. a. \\
\hline & Rough estimate of use values & n. a. \\
\hline 7 & Conservation values & n. a. \\
\hline 7.1 & Existence values & n. a. \\
\hline 7.2 & Option values & n. a. \\
\hline 7.3 & Bequest values & $\mathbf{4 9 7 . 4 2}$ \\
\hline 8 & Cultural values & $\mathbf{1 0 1 0 6 4 9 9 . 4 3}$ \\
\hline & Non-use values & Rough estimate of Total Economic Value (TEV) \\
\hline & Rough estimate of Total Economic Value (TEV), \\
\hline
\end{tabular}

While the origins of environmental economics date back, at least, to the 1920 s, environmental valuation started from the 1950s onwards when environmental policy instruments were established in the US and later in Europe. In their wake it became mandatory to assess environmental costs and benefits (initiated mainly by governments) of large infrastructure projects. Environmental economists, who try to include ecosystems into the real economy, emphasize the four contributions of natural ecosystems to the human economy (Turner et al. 1994): to supply natural renewable as well as non-renewable resources, to assimilate waste originating from human activities, to represent a system of life support on Earth (ecosystem services), and to conserve natural landscape assets and amenities.

Most experts, focusing on the assessment of the role of nature, maintain that if humans are dependent on the quality of ecosystem services, their total value for the economy and for human society may be infinite (e. g. Constanza et al. 1997). Some environmental valuation studies in the Central European context, such as those by Kosz (1996), Getzner \& Jungmeier (2002), Getzner (2002, 2003, 2009, 2010), Bednar-Friedl et al. (2011) and Strobel (2010), assess costs and benefits of environmental conservation. A comprehensive overview of the economic, social and ecological assessment of ecosystem services can be found in the work of Newcome et al. (2005), while basic information on the evaluation of ecosystem services is provided by Defra (2007). Basic overviews of the existing knowledge and experience on the assessment of ecosystem services is gathered in Seják \& Dejmal (2003) and Hu- berman (2008) who put together a bibliography of international publications. A prominent example of such an individualist preference assessment is, for example, the paper by Constanza et al. (1997) who put the annual value of ecosystem services of the world's ecosystems to USD 16-54 trillion, which means the value of ecosystem services worldwide (mean value of USD 33 trillion) may be about 1.8 times the annual global GDP (USD 18 trillion for 1997). These values were based on studies assessing individual willingness to pay for particular ecosystem services.

In Slovakia there are only partial studies, such as the assessment of public functions of forest and agricultural ecosystems (Merganič \& Merganičová 2007; Tutka et al. 2009) and an economic evaluation of nature conservation functions of forest ecosystems (Tutka 2011). A primary complex assessment of ecosystem services in protected areas was done in two national parks in Central Europe (Getzner 2009, 2010), in the Tatra NP (Poland) and in Slovenský Raj NP (Slovakia). Považan et al. (2014) provide partial results of the assessment of benefits of biodiversity protection in Vel'ká Fatra NP, and include a comparison of the valuation results with the two aforementioned NPs. All areas were assessed by the same methodology with the aim to gain comparable results. Füzyová et al. (2009) and Švajda et al. (2013) have evaluated the recreational function (benefits) by computing travel costs in the Tatra NP. Ecosystem services in forests of Slovakia are dealt with in Čaboun et al. (2010); Janiga et al. (2012) describes profits of companies in protected areas. A rapid assessment of ecosystem services in the Carpathian protected areas was given in the guidelines by WWF (Bucur \& Strobel 2012). The European Union also deals with the issue of ecosystem services. It aims to stop biodiversity loss and ecosystem services degradation in the EU by 2020 and to renew them as much as possible as an important contribution in a fight against biodiversity loss (Mandate EU 2012). A recent study of the EC estimates that the benefits of Natura 2000 would be more than 3 to 7 times the cost of establishing such a protected area (EEA Report No 5/2012; Gantioler et al. 2014).

\section{Methodology}

Považan \& Kadlečík (2014) provide a case study methodology testing and assessing ecosystem services in the protected areas of Slovakia. The first step of the assessment for the case study dealt with in this paper was collecting and interpreting ecological data on ecosystem services in Muránska Planina NP. Basic collection of data on the selected ecosystem services was done with the help of local and regional experts, as well as of the Muránska Planina NP administration. A questionnaire survey directly on-site among the visitors of the protected area was part of the assessment. The questionnaire focused on finding preferences of the visitors and their willingness to pay (WTP) an en- 


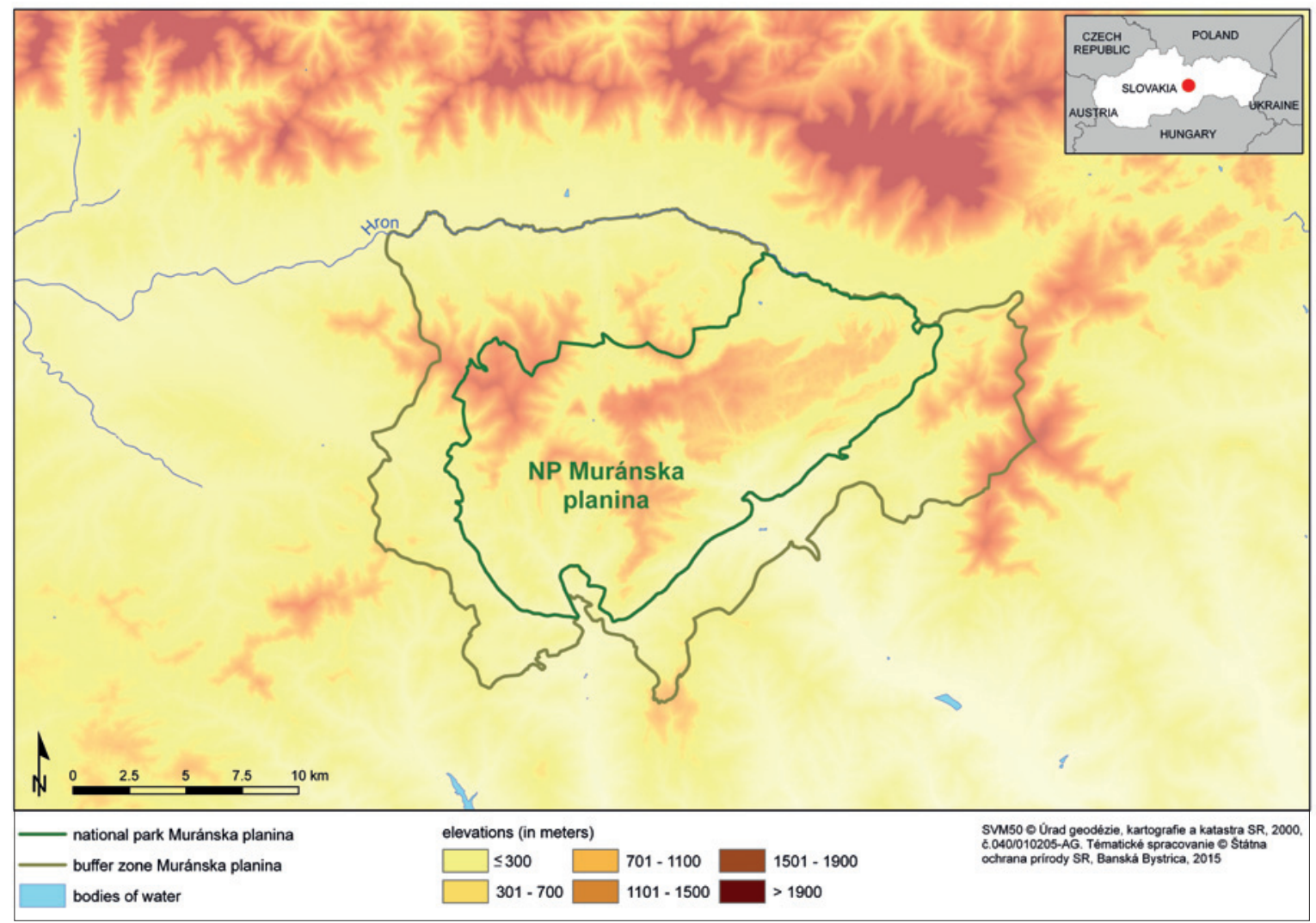

Figure 1 - Map of Muránska Planina NP. Source: State Nature Conservancy of the Slovak Republic

try fee to the protected area, and a willingness to accept (WTA) certain restrictions in the protected areas; preferences of visitors for the development of the NP and for a brand of the Muránska Planina NP were also gauged. The field work was done with the involvement of disadvantaged groups of students (e.g. member of Roma families and unemployed people) who were trained for the data collection. The sample consists of 472 visitors of Muránska Planina NP interviewed between April and September 2013. Table 1 represents an overview of ecosystem services which were assessed within finding a value of ecosystem services in Muránska Planina NP.

Based on existing assessment studies and databases, the values and benefits expressed in monetary values were adjusted to the local and / or national conditions (e. g. based on income, GDP and further socio-demographic data). The assessment of the survey data was done by statistical analyses (SPSS software). Finally, individual values were grouped, for example, along the number of visitors per year, in order to estimate potential values of ecosystem services provided by Muránska Planina NP.

\section{Study area}

The following description of Muránska Planina NP (Muran Plateau) is based on the work of Šmídtová (2013). Muránska Planina NP and its protective (core) zone are located in the Inner Western Carpathians in the geomorphological units of Spišsko-Gemerský Karst, Stolické Mountains and Horehronské Valley. The Muran Plateau is a substantial and indicative representation of the karst plateau. The highest peak area (including the protection zone) is Stolica (1476 m).

The NP is located at the border of central and eastern Slovakia. The territory can be defined by the municipalities of Tisovec, Muráň, Muránska Huta, Červený Kameň, Závadka nad Hronom, Beňuš and Pohronská Polhora. It extends into three political / administrative districts (Brezno, Revúca and Rimavská Sobota). The area of Muránska Planina was classified as a Protected Landscape Area as early as 1976 for its preservation and precious natural heritage. In 1997 it was declared a NP with an area of 20318 hectares. Almost the entire area of the NP is currently classified as a Site of Community Importance within the Natura 2000 system of protected areas, which includes the rarest and most endangered habitats and species in the European Union member states. In the most valuable parts of the territory, separate nature reserves and protected areas have been defined. The system of nature reserves has been gradually built up since 1953 and today consists of 26 areas with the highest levels of protection. However, contrary to its great importance, the NP does not currently have a valid management plan. 


\section{Results}

The next section briefly describes the various products and ecosystem services of Muránska Planina NP and their monetary value.

\section{Forest products and ecosystem services}

The forests of Muránska Planina NP extend over an area of 17355 ha, representing $85.4 \%$ of the NP territory. In the buffer zone of the NP, $65.1 \%$ of the area or 14127 ha are forests. In the area of the NP, 64\% (11177 hectares) are commercial forests, 34\% (5874 ha) are protective forests, and 2\% (304 ha) are forests of special purpose. Muránska Planina NP is one of the most important reservoirs of groundwater in Slovakia. Information about the area and the categorization of forest land ownership in Muránska Planina NP was provided by SNC, by the NP administration and by extracting data from GIS layers. State-owned forests cover $86 \%$ of the NP area. Other forests are owned by municipalities, land associations, private landowners or by the church. When calculating rates of wood, we used the average price of deciduous and coniferous timber listed in the Green report (2012). The structure types of harvested wood in Muránska Planina NP are not recorded separately, so we used a mean value of the timber price. Annual timber production in Muránska Planina NP is worth EUR 3549 million per year, of which EUR 2507 million come from softwood and EUR 1042 million from hardwoods. Typical other forest products are forest plants, including fruit, especially strawberries, blueberries, cranberries, raspberries, and mushrooms. In the Muránska Planina NP, as well as in all other Slovak NPs (the third level of nature protection), collecting plants (and mushrooms) is prohibited, including fruit, so we do not take this category into account. Collecting seeds of forest trees is rather irregular because the plants do not produce the same number of seeds every year and the low harvest of seeds would be unprofitable. Since 2006 seeds from beech, spruce and fir have been collected in Muránska Planina NP. The price of seeds is based on the price list from the civic association Semenoles Liptovský Hrádok (2013). The value of the average annual production of seeds collected in Muránska Planina NP only amounts to EUR 740 per year. However, the slopes of Muránska Planina NP provide very good production conditions for beekeeping. In addition to 70 permanent colonies, which are managed by five local beekeepers, additional beekeepers are drawn to the area during flowering of lime, raspberry and honeydew, bringing with them up to 250 further colonies. The average price of honey is EUR 5 per $\mathrm{kg}$, the pollen price is EUR 26 per $\mathrm{kg}$ (by local beekeepers). The value of the average annual production of bee products in Muránska Planina NP is thus about EUR 49150 EUR. Data on bee management have been provided by local beekeepers during personal meetings.
The area of Muránska Planina NP belongs to the Hron and Slaná river basins. It is an area with significant natural accumulation of water and, based on the Water Act no. 346/2004 Coll, it was declared a Protected Water Area (PWA). The PWA Muránska Planina is located in the Rimavská Sobota and Revúca districts. There are four water management springs: Horný Tisovec, Dolný Tisovec, Pod Hradom and Bobačka.

Calculation of the value of water supply (VWP) (with reference to Bucur \& Strobel 2012)

$$
\begin{gathered}
\mathrm{VWP}=\mathrm{Nm}^{*} \text { Uaw } * \mathrm{Pmw} \\
\mathrm{VWP}=27300 * 25 \mathrm{~m}^{3} * 1.4285 \mathrm{EUR} / \mathrm{m}^{3} \\
=\mathrm{EUR} 975975
\end{gathered}
$$

$\mathrm{Nm}$ - the average number of people who use water from the protected area

Uaw $\left(\mathrm{m}^{3}\right)$ - average water consumption per person per year Pmw $\left(E U R / \mathrm{m}^{3}\right)$ - average regional price of water per year

We contacted a number of organizations about information on the flood protection and water retention capacity of the NP area, (e.g., Slovak Water Management Enterprise, Slovak Hydrometeorological Institute, Ministry of Environment, State Nature Conservancy of the Slovak Republic, Forests of the Slovak Republic, as well as municipalities). Unfortunately, no studies have been carried out on water retention, flood protection and protection against erosion in this area. In order to value the water retention capacity despite the lack of primary valuation studies for Muránska Planina NP, mean values from $27 \mathrm{EU}$ countries had to be taken as a reference. These were then adapted to a national economic context by multiplying these values with the respective relative income differential for Slovakia as the most simple method of transferring benefits between countries from a study site to the current policy site (for benefit transfer cf., for instance, the recent reviews by Wilson \& Hoehn 2006; Lindhjem \& Navrud 2008). Getzner (2009) points out that the values for forest ecosystem functions related to water retention and flood protection in several international studies range from EUR 45 to 150 per hectare (cf. also Croitoru 2008). Chiabai et al. (2009) put the marginal value of all provisioning services of forest ecosystems (type of biome: temperate mixed) at EUR 107 per hectare (this value also includes erosion control). Krieger (2001) estimates the value of water regulation and erosion control to be around EUR 90 per hectare. For Pearce (2001) the value of flood control is about EUR 45 per hectare. However, as income levels are different, the average unit value (per hectare) of EUR 90 for water retention services has to be adapted. The average GDP for Slovakia is about $76 \%$ of the EUR 27 average (EUROSTAT 2013). Taking this ratio as a basis for transferring the monetary value, we can approximate the above-mentioned value to EUR 68.4 per hectare per year. 
Calculation of the value of water retention (VWR), flood protection (with reference to Bucur \& Strobel 2012)-Valuation technique: reference values related to replacement/avoided costs

$$
\begin{gathered}
\text { VWR }=\mathrm{A} * \text { Vmwr } * \text { ID } \\
\text { VWR }=[6178 \text { ha } * 90 \mathrm{EUR} / \text { ha } * 0.76]+[11177 \text { ha } \\
* 36 \mathrm{EUR} / \text { ha } * 0.76]=422575.2+305802.72 \\
=\text { EUR } 728378
\end{gathered}
$$

A (ha) - Protected area surface

Vmwr (EUR / ha) - Mean value of water retention (for EU27; as for unmanaged forests)

ID - Income differential, which is GDP per inhabitant minus PPP (purchasing power parity)

Forests in Slovakia are divided into 3 categories depending on the predominant function which they provide. Special-purpose forests and protective forests cover 6178 ha of the NP area (unmanaged forests); commercial forests (managed forests) are managed on 11177 ha. The total forested area is 17355 ha (source: NP Administration). It is assumed that commercial forests perform their water retention function only to $40 \%$ compared with forests without direct human intervention (Ceroni 2007). Therefore we used to calculate the value of 11177 hectares under commercial forest management at 27.36 EUR/ha and 6178 ha of special-purpose forests and protective forests at $68.4 \mathrm{EUR} / \mathrm{ha}$. The water retention value (including erosion control functions) then comes to 728377.92 EUR/year.

The rate and the positive benefits of carbon sequestration in Muránska Planina NP is hard to gauge since the increase of forest biomass and timber is offset by logging and felling inside and outside of the NP, as well as by decomposition left in the stands. The total annual increase in conifer forests in Muránska Planina NP was $67281 \mathrm{~m}^{3}$, and the total annual growth of deciduous trees in forests in Muránska Planina NP was $57192 \mathrm{~m}^{3}$, totalling $124473 \mathrm{~m}^{3}$. The carbon sequestration is certainly an important ecosystem service in areas with no economic use of forests; in the NP an area of just 6178 ha falls in this category. In the rest of the area (11 $177 \mathrm{ha})$ carbon sequestration is not relevant (commercial forests).

Calculation of carbon sequestration (VCS) (with reference to Bucur \& Strobel 2012) - Valuation technique: market prices

$$
\begin{gathered}
\mathrm{VCS}=\mathrm{A} * \operatorname{Vmcs} * \mathrm{ID} \\
\mathrm{VCS}=6178 \mathrm{ha} * 12 \mathrm{EUR} / \mathrm{ha} * 0.76 \\
=56343.36 \mathrm{EUR}
\end{gathered}
$$

A (ha) - Protected area surface

Vmcs (EUR / ha) (12 EUR / ha) - Mean value of carbon

sequestration (unmanaged forests)

ID (0.76 for Slovakia) - Income differential (EU27)

The calculated average value of carbon sequestration is $12 \mathrm{EUR} / \mathrm{ha} /$ year. This value includes the national GDP differential of Slovakia compared to the average of the EU27 and comes to $9.12 \mathrm{EUR} / \mathrm{ha} /$ year. For the entire region, the value of carbon sequestration amounts to EUR 56000 EUR/year.

Erosion control is a part of the valuation of water retention and flood protection, as described above. As with other non-timber forest products, it is not allowed to collect medicinal products, e. g. medicinal plants within the national parks of Slovakia; thus, no direct use value of medicinal plants can be calculated. Collecting (medicinal) plants is, however, allowed for personal use only. No data are available on this ecosystem services, so we have to leave out the personal use of medicinal plants.

\section{Agriculture and ecosystem services}

Agricultural land covers about $10 \%$ of the NP area. Grasslands are the largest agricultural land cover; arable land occupies only about $0.1 \%$ of Muránska Planina NP. Overall, however, only about $60 \%$ of all agricultural land is now used. The remaining part is overgrown with trees and shrubs of various age, structure and composition. Grasslands are used for grazing livestock, mainly sheep and some cattle. In recent decades, management of grasslands (pastures) has not been consistent, with a trend toward re-forestation. Parts of the grassland are not properly managed and are being gradually overgrown or abandoned. With the progress of secondary succession, the biodiversity typical for alpine pastures has decreased. Traditional farming, i. e. using pastures for grazing livestock, would thus be in the interest of biodiversity conservation. Parts of the meadows are currently used by the Slovak State Forests for breeding half-wild horses of the Noriker type. Supporting the grassland habitats by horse breeding is important to keep meadows in the upper part of Muránska Planina in a good conservation status.

Sheep farming is seasonal - in summer only; sheep are housed outside the NP during winter. Sheep farms (chalets) are found in several locations and usually temporary. In some localities grassland pastures are used for livestock breeding. In typical horse breeding the meadows are being grazed gradually from spring to autumn by driving the animals on in intervals of several weeks.

To determine the value of agricultural products, we used information about products and prices, which we got from representatives of local farmers and cooperatives. Whereas nearly all agricultural entities operate not only on the territory of the NP, but (especially) in the surrounding area, total production and profits 
from farming have not been taken into account. We used the value of the potential of grasslands established on the basis of their productivity (weight of hay per hectare). The annual agricultural output in Muránska Planina NP amounts to EUR 203000. Fishing is organized by the Slovak Fishing Association (SRZ) and the state-owned enterprise of the Slovak State Forests. In Muránska Planina NP there are three local fishing organizations (Tisovec, Revúca, and Brezno). However, fishing activities are very low inside the park's boundaries as the Alpine rivers and creeks are not significant habitats for fish. There are 11 hunting grounds in the NP, managed similarly to hunting grounds in areas that are not protected. The value of the bunting production (2012) inside the park can be put at EUR 54000 per year, based on the value of hunting licenses and the market prices of venison.

\section{Recreational and existential values}

About 30000 tourists visit Muránska Planina NP every year (rough estimate by the NP administration, 2013). This number is very low compared to other Slovak national parks. The development of tourism and recreational and sporting activities is not as significant as in other regions of Slovakia (e.g. High Tatras, Low Tatras and Slovak Paradise). On the other hand, Muránska Planina NP is officially the $101^{\text {st }}$ European Charter Area (and the first in Slovakia) assigned by the EUROPARC Federation in 2012. Today the NP can be seen as a Charter pilot and role model for other protected areas in Slovakia. Partners and colleagues from outside the Charter Area are already requesting information from Muránska Planina NP on how to initiate such a process for other protected areas (EUROPARC Federation 2014). The NP territory does not include larger settlements and is distant from main roads and communication links. The area of the NP is certainly suitable for various forms of recreational and sporting activities, while access by motor vehicles is largely restricted. Hiking (about $310 \mathrm{~km}$ of marked hiking trails) associated with bivouac and camping trips, ski touring, cycling, canoeing and rafting (River Hron) represent the dynamic forms of tourism in the NP. In recent years there has been a development of less traditional forms of physical activity, such as horse riding and paragliding. Climbing is not very developed and is limited to two sites (Javorníková Valley and Tesná Skala). Other forms of outdoor activities include family and group picnics, excursions and speleotourism. Two places for overnight stays in nature (Nižná Kl'aková and Pätina tourist huts) and two sites with controlled fireplaces are located inside the park. Two nature trails have been established (Vel'ká Lúka - Muráň Castle and Stožky) and one visitor site (Piecky). Two seasonally operated information centres (Muráň and Tisovec) are available to NP visitors. The average length of stay of survey respondents in Muránska Planina NP was 2.29 days (authors' own survey). We thus presume that Muránska Planina NP is not a typical destination for an extended vacation but rather for short-term trips (e. g. weekends) or day trips without overnight stays. For the valuation of recreational values of visitors in protected areas, it is generally important to distinguish between visitors who have come specifically to visit the NP and those who had other motives to visit the region. In the first case, the travel to this area is closely related to the existence of the NP (the major motive for the visit is the NP), while in the second case, other motives for the visit dominate which are not directly related to the NP (e.g. a stop on the way to another destination, visiting family or friends). Regarding the recreational value a measure of transport costs (travel costs) is usually considered a reliable tool, where the motive for the visit of the area is closely related to the NP. In the other type of visit the transportation costs can be attributed to other motives and therefore only partially add to the recreational value of the NP park (Getzner 2010). The largest share of visitors comes to the region for reasons other than visiting Muránska Planina NP (41\%, 190 respondents). On average, respondents spent 2.98 hours on the road to visit the NP; many visitors travelled up to 5 hours. The distance from the home of the respondent to the NP averaged $218.51 \mathrm{~km}$ (this figure is distorted by visitors from the U.S. and Australia), the median distance was $100 \mathrm{~km}$ (mode value $60 \mathrm{~km}$ ). Total travel expenses were calculated by means of various expenditure categories (accommodation, food, shopping, entrance fees, museums, transportation, sports) from the visitor survey. On average visitors spent $65.36 \mathrm{EUR} /$ day/person in the national park region. Most was spent on food, accommodation and shopping. If we consider only the cost of transportation, parking and museums (expenses directly associated with visiting the park, other expenses would occur anyway outside the protected area in everyday life or in other tourist destinations), this figure is EUR 7.78 per day and visitor. Important for the local economy is certainly visitor spending on food (EUR 23.89 per person and day), accommodation (EUR 15.73 per person and night) and shopping at local stores (EUR 8.23 per person and day). In this way the existence of the NP supports the local economy. Total expenditure per visit per person is assessed based on the median of the travel costs (EUR 65.36, respectively EUR 7.78 per day; see above). Combined with the average length of stay of 2.29 days, we can estimate the total expenditure as EUR 149.67 per person and stay. A specific survey question related to the place of accommodation to assess the potential economic importance of the park for the region. Approximately half of the respondents do not stay overnight in the region. The other half used the accommodation inside the NP or in villages nearby. As mentioned before, the total number of visitors in Muránska Planina NP is 30000 per year, making it one of the least visited national parks in Slovakia. 
Calculation of recreational value (with reference to Bucur \& Strobel 2012) ${ }^{1}$

$$
\begin{gathered}
\mathrm{VRT}=\mathrm{Sm} * \mathrm{DM} * \mathrm{~N} \\
\mathrm{VRT}=65.36 * 2.29 * 30000=4490232 \mathrm{EUR}
\end{gathered}
$$

If we take into account transport costs only, the mean value of recreational benefits would amount to:

$$
\mathrm{VRT}=7.78 * 2.29 * 30000=534486 \mathrm{EUR}
$$

VRT- Recreational value SM (EUR) - Average value of expenditures per person per day

DM - Average length of stay

$\mathrm{NV}-$ Average number of visitors

We can now obtain the total economic value of ecosystem services for one year (TEV) by summing up all partial values. We took into account only the direct and indirect use value, since their calculation is easier (see Table 1). It should be noted that the true total economic value represents an even broader framework.

Although the issue of the assessment of ecosystem services has not yet been solved completely, there is a clear consensus on the need for their evaluation. The biggest question marks hang over various assessment methods. However, all approaches point to high value biodiversity with a number of services essential for human welfare.

The results clearly show that Muránska Planina NP provides important ecosystem services that can also be expressed in financial terms. Its services return values which also contribute significantly to the local economy.

The survey also highlighted that visitors prefer activities and models of tourism specific to national parks. On the one hand, destinations may offer many attractions, such as ski slopes, and aqua parks, wellness; on the other hand, so-called green (soft) tourism (eco-tourism) may respect and use local specificities, such as the landscape and local products. Visitors of Muránska Planina NP clearly prefer the development of green tourism (up $82.4 \%$ of respondents) to commercial tourism (17.6\% of respondents).

It should be noted that this study has not quantified non-use values of the protected area (existence value, conservation value, option value) owing to the limited capacity of the visitors' survey and the concentration on direct benefits (use values) of Muránska Planina NP.

\footnotetext{
Usually, the recreational value would have to be computed based on an econometric estimate of the demand curve relating trip frequency of visitors to travel costs borne to reach the park. This calculation thus results in a calculation of the consumer surplus per trip; owing to simplicity, this paper leaves out more advanced models of consumer surplus computation and simply aggregates the recreation value by accounting for the expenditure of visitors to the park.
}

\section{Conclusions}

The main objective of this case study was to evaluate (and value) ecosystem services in Muránska Planina NP. The importance of ecosystem services is enormous for human life. The value of ecosystem services is around EUR 10.1 million per year in Muránska Planina NP. The most valuable ecosystem service of the park is the recreational function (up to EUR 4.5 million per year), although the region is not frequently visited (only approx. 30000 visitors per year). The value of timber production is at a lower level, despite the fact that it is a forest area (about EUR 3.5 million per year). Other important ecosystem services include the supply of drinking water (EUR 980000 per year) and water retention and flood control (EUR 730000 per year). A beneficial activity for providing services is extensive farming - its products can be valued at EUR 203000 per year. Less significant benefits are carbon storage, hunting or benefits from other forest products.

The annual aggregated value per hectare amounts to EUR 497. It should be noted that the study has not quantified non-use values of the protected area (existence value, conservation value, option value).

The results of this and other environmental valuation studies in protected areas in Slovakia suggest that - from an economic point of view - it would be highly beneficial to invest in the conservation of biodiversity and to sustainably fund the establishment and effective management of NP. While several European countries have committed themselves to providing adequate financing for their protected areas, Slovakia is still lagging behind, and the benefits of ecosystem services are downplayed in comparison to the potential economic benefits of intensive development of tourism and extractive branches of the economy in the protected areas, especially in national parks. The importance of ecosystem services can help to shape strategies in the context of sustainable development. If this concept is taken seriously, a new legislative process should follow in order to ensure effective conservation of biodiversity and eventually to design payment schemes of ecosystem services and a system of ecosystem services accounting.

Since visitors of Muránska Planina NP clearly prefer the development of green tourism (ecotourism), we recommend expanding the options of eco-tourism in the region. Further management plans should account for these preferences and thus focus on tourists with appropriate access to visitor facilities according to European Charter for Sustainable Tourism in Protected Areas.

\section{References}

Bucur, C. \& D. Strobel 2012. Valuation of Ecosystem Services in Carpathian Protected Areas - Guidelines for rapid assessment. Braşov. 
Bednar-Friedl, B., D. Behrens \& M. Getzner 2011. Socioeconomics of conservation in the Alps. In: Schmidt, J.G. (ed.), The Alpine Environment: Geology, Ecology and Conservation: 135-152. Hauppauge (NY).

Ceroni, M. 2007. Ecosystem services and the local economy in Maramures Mountains nature park, Romania. Final report, mimeo, Burlington (VA).

Chiabai, A., C.M. Travisi, H. Coding, A. Markandya \& P. Nunes 2009. Economic valuation of forest ecosystem services: Methodology and monetary estimates. Fondazione Eni Enrico Mattei Nota di Lavoro 12.2009, FEEM, Milano.

Constanza R., R. D'Arge, R. De Groot, S. Farber, M. Grasso, B. Hannon, K. Limburg, S. Naemm, R. V. O’Neill, J. Paruelo, R. G. Raskin, P. Sutton \& M. Van De Belt 1997. The value of the world's ecosystem services and natural capital. Nature 387: 253-260.

Croitoru, L. 2008. Value of mediterranean forests. Encyclopedia of the Earth. Available at: http:// www.eoearth.org/view/article/156822/ (accessed: 30/11/2014)

Čaboun, V., J. Tutka \& M. Moravčík (eds.) 2010. Uplatñovanie funkecii lesa v krajine. Národné lesnicke centrum vo Zvolene [In Slovak].

DEFRA - Department for Environment, Food and Rural Affairs 2007. An Introductory Guide to valuing ecosystem services.

EEA 2012. Report No 5/2012. Available at: http:/ / www.eea.EURopa.eu/highlights/protectedareas-have-increased-to?\&utm_campaign=protectedareas-have-increased-to\&utm_medium=email\&utm_ source $=$ EEASubscriptions (accessed: 20/2/2013)

Ehrlich, P.R. \& A.H. Ehrlich 1992. Healing the Planet. New York.

Europarc Federation 2014. European Charter for Sustainable Tourism in Protected Areas. First Charter area in Slovakia. Available at: http://www. european-charter.org/news / discover-our-charterareas/muranska-planina-national-park/ (accessed: 31/12/2014)

EUROSTAT 2013. GDP per capita in PPS. Available at: http://epp.EURostat.ec.EURopa.eu/ tgm/table.do? tab $=$ table\&init $=1 \&$ plugin $=1 \&$ language $=$ en\&pcode $=$ tec00114 (accessed: 20/12/2013)

Füzyová, L', D. Lániková \& M. Novorolský 2009. Economic Valuation of Tatras National park and Regional Environmental Policy. Polish Journal of Environmental Studies 18(5): 811-818.

Gantioler, S., M. Rayment, P. ten Brink, A. Mcconville, M. Kettunen \& S. Bassi 2014. The costs and socio-economic benefits associated with the Natura 2000 network. International Journal of Sustainable Society 6(1-2): 135-157.

Getzner, M. 2002. Ecotourism, Stakeholders and Regional Sustainable Development. In: Hagedorn, K. (ed.), Environmental Management and Institutional Change: 315 - 341. Cheltenham.

Getzner, M. 2003. The economic impact of national parks: the perception of key actors in Austrian national parks. International Journal of Sustainable Development 6(2): 183-202.

Getzner, M. 2009. Economic and cultural values related to Protected Areas. Part A: Valuation of Ecosystem Services in Tatra (PL) and Slovenský Raj (SK) national parks. Final report, 13 November 2009.

Getzner, M. 2010. Economic and cultural values related to Protected Areas. Der Oeffentliche Sektor Forschungsmemoranden 1-2/2010.

Getzner, M. \& M. Jungmeier 2002. Conservation policy and the regional economy: the regional economic impact of „Natura 2000” conservation sites in Austria. Journal for Nature Conservation 10(1): 25-34.

Getzner, M. \& M. Jungmeier (eds.) 2009. Improving Protected Areas. Klagenfurt.

Huberman, D. 2008. A Gateway to PES. Using Payments for Ecosystem Services for Livelihoods and Landscapes. Markets and Incentives for Livelihoods and Landscapes Series No. 1. Forest Conservation Programme, International Union for the Conservation of Nature (IUCN), Gland.

Janiga, M., K. Markuljaková, O. Mahút, P. Pogányová, Z. Kohútová, J. Šulavík, A. Boháčová, N. Herian, Z. Ivaničová, M. Veselská, D. Štefancová, M. Ištoňa, P. Tichý, J. Kvanda, P. Mikoláš, F. Griga, S. Chovancová, M. Adamová, E. Lisštiaková, J. Gašperanová, V. Kozárik, D. Hruška, M. Podracká, M. Masaryk, M. Novisedláková, J. Thomková, J. Kmacík, V. Karkoszková, P. Bugáň, M. Šudila \& P. Richtárech 2012. Revenues of stakeholders in the national parks and landscape protection areas of the Slovak Republic. Oecologia Montana. International Journal of Mountain Ecology 21(2): 1-34.

Kosz, M. 1996. Valuing Riverside Wetlands: the Case of the „Donau-Auen“ National Park. Ecological Economics 16(2): 109-127.

Lindhjem, H. \& S. Navrud 2008. How reliable are meta-analyses for international benefit transfers? Ecological Economics 66(2-3): 425-435.

Lyons, K., C. Brigham, B. Traut \& M. Schwartz 2005. Rare species and ecosystem functioning. Conservation biology 9(4): 1019-1024.

Mandate EU 2012. Working group on Mapping and Assessment of Ecosystems and their Services (MAES) (final version: December 2012). European Commission Directorate-General Environment Directorate B - Nature, Biodiversity \& Land Use ENV.B.2 - Biodiversity.

Merganič, J. \& K. Merganičová 2007. Funkcie biodiverzity a jej nepeñažná a ekonomická kvantifikácia. Čiastková správa pre APVT projekt APVV-27019805 „Hodnotenie verejnoprospešných funkcií lesných a pol'nohospodárskych ekosystémov a služieb odvetvi“". [n Slovak]

Newcome, J., A. Provins, H. Johns, E. Ozdemroglu, J. Ghazoul, D. Burgess \& K. Turner 2005. The Economic, Social and Ecological Value of Ecosystem Services: A Literature Review. Final report prepared for: The Department for Environment, Food and Rural Affairs (Defra) by: Economics for the Environment Consultancy (eftec). 
Pearce, D. 2001. The economic value of forest ecosystems. Ecosystem Health 7(4): 284-296.

Pearce, D. \& D. Moran 1994. The Economic Value of Biodiversity. IUCN, The World Conservation Union, Earthscan Publications, London.

Považan R., M. Getzner \& J. Švajda 2014. Value of Ecosystem Services in Mountain National Parks. Case Study of Vel'ká Fatra National Park (Slovakia). Polish Journal of Environonmental Studies 23(5): 1699-1710.

Považan, R. \& J. Kadlečík 2014. Hodnotenie ekosystémových služieb v chránených územiach Karpát so zameraním na Slovensko - Príruckea pre rýchle hodnotenie. Msc. [In Slovak]

Reid, W.V., H.A. Mooney, R.A. Cropper, D. Capistrano, S.R. Carpenter, K. Chopra, P. Dasgupta, R. Dietz, A.K. Duraiappah, R. Hassan, R. Kasperson, R. Leemans, R.M. May, R. McMichael, P. Pingali, C. Samper, R. Scholes, R.R. Watson, A.H. Zakri, Z. Shidong, N.J. Ash, E. Bennet, P. Kumar, M.J. Lee, C. Raudsepp-Hearne, H. Simons, J. Thonell \& M.B. Zurek 2005. Millenium Ecosystem Assesment - Ekosystémy a lidský blabobyt. Syntéza, World Resource Institute, Centrum pro otázky životního prostředí. Univerzita Karlova v Prahe, Praha. [In Czech]

Sabo, P., P. Urban, I. Turisová, R. Považan \& K. Herian 2011. Obrozenie a ochrana biodiversity. Vybrané kapitoly z globálnych environmentálnych problémov. Centrum vedy a výskumu (Ústav vedy a výskumu), Inštitút výskumu krajiny a regiónov, Univerzita Mateja Bela v Banskej Bystrici, Katedra biológie a ekológie, Fakulta prírodných vied, Univerzita Mateja Bela v Banskej Bystrici \& občianske združenie Živica. [In Slovak]

Seják, J. \& I. Dejmal (eds.) 2003. Hodnocení a oceňování biotopi Ceské republiky. Český ekologický ústav. [In Czech]

Stohlgren, T., D. Binkley, G.W. Chong, M.A. Kalkhan, L.D. Schell, K.A. Bull, Y. Otsuki, G. Newman, M. Bashkin \& Y. Son 1999. Exotic plant species invade hot spots of native plant diversity. Ecological monographs 69(1): 25-46.

Strobel, D. 2010. Guidelines on the Valuation of Ecosystem Services of Protected Areas [Draft version]. WWF Danube-Carpathian Programme, Vienna.

Šmídtová, J. 2013. Charakteristika územia NP Muránska planina (msc.).

Švajda, J., M. Getzner \& R. Považan 2013. Visitor's perceptions and economic effects of the Tatra
National Parks in Poland and Slovakia. In: Šauer P., D. Švihlová, A. Dvořák, A. Lisa (eds.), Visegrad Countries: Environmental Problems and Policies: 118-125. Prague.

TEEB (2010). The Economics of Ecosystems and Biodiversity: Ecological and Economic Foundations. London and Washington.

Turner, R.K., D. Pearce \& I. Bateman 1994. Environmental economics: an elementary introduction.

Tutka, J., J. Vilček \& M. Kovalčík 2009. Oceňovanie verejnoprospešných funkecii lesných a polnohospodárskych ekosystémov a služieb odvetví. Odborný seminár: Aktuálne otázky ekonomiky LH SR. Zvolen 21-22 október 2009. [In Slovak]

Tutka, J. 2011. Ekonomické hodnotenie prírodo-ochranných funkecii lesných ekosystémov. Odborný seminár: Aktuálne otázky ekonomiky LH SR Zvolen 8. december 2011. [In Slovak]

Wilson, M.A. \& J.P. Hoehn 2006. Valuing environmental goods and services using benefit transfer: the state-of-the art and science. Ecological Economics 60(2): 335-342.

\section{Authors}

\section{Radoslav Považan}

is a biodiversity expert (Civil Association Pronatur) and future environmental scenario expert (Slovak Environment Agency), Slovakia. Main fields of research: biodiversity, ecosystem services, tourism and environmental information and scenario building. Email: radopovazan@gmail.com

\section{Michael Getzner}

is Professor of Public Finance and Infrastructure Economics, Vienna University of Technology (Austria); main fields of research: public finance, infrastructure policy, ecological and environmental economics. Email: Michael.getzner@tuwien.ac.at

\section{Juraj Švaja}

is Assistant at Matej Bel University in Banská Bystrica (Slovakia). His research interests focus on protected area management, including valuation of ecosystem services in national parks. Email: juraj. svajda@gmail.com 